\title{
Postsecularism and Contemporary Spirituality
}

\author{
Karol Jasiński* \\ karol.jasinski@uwm.edu.pl \\ https://orcid.org/0000-0002-7695-499X
}

https://doi.org/10.31192/np.18.1.1

UDK / UDC: $2-58$

299.5

Izvorni znanstveni rad / Original scientific paper Primljeno / Received: 3. prosinca 2019. / Dec 3, 2019 Prihvaćeno / Accepted: 2. veljače 2020. / Feb 2, 2020

The author of the article attempted to define the character of contemporary, new form of spirituality and show its connections with religion. The appearance of a new kind of spirituality is the result of processes taking place in social life. On the one hand, it is marked by secularization and secularism, on the other, it is desecularization and post-secularism. The analyzes were based on the belief that a new spirituality alone is insufficient in the life of a particular man, but it must find a complement to some religion. The article consists of three parts. In the first one the following phenomena were discussed: secularization, secularism, post-secularism. The second part analyzes the phenomenon of new spirituality. In the third, however, attention was drawn to the issue of religion, the traditional understanding of spirituality and the nature of the relationship between religion and spirituality.

Key words: individualism, institution, postsecularism, religion, spirituality, spiritual search.

\footnotetext{
* Karol Jasiński, PhD, Assoc. Prof., Faculty of Theology, University of Warmia and Mazury in Olsztyn; Address: Hozjusza 15, 11-041 Olsztyn, Poland.
} 


\section{Introduction}

Three important terms are used in the contemporary religious discourse: religion, religiousness and spirituality. Religion and religiousness are often treated as interchangeable concepts. However, one notices a tendency to juxtapose a formalised religion with a dynamic attitude towards God in the form of religiousness. Religion is characterised by staticity, passivity and rigid structures, and religiousness - by dynamism, creativity and a living relationship with the Absolute.

Another concept that is very popular today is spirituality, which can be linked to or independent of religion. Spirituality is also understood as an inner deepening of the content of faith, a more conscious religious experience, contact with a certain transcendent being and reflection on the nature of the "spirit" as its basis. It is clear that spirituality is a multifaceted concept. Despite this, today people are said to feel a "hunger" for spirituality and to seek new forms of spirituality.

The following analyses are an attempt to define the character of the contemporary form of spirituality and to show its relations with religion against the background of the processes taking place in social life. In society, we deal with secularisation and secularism on the one hand, and on the other - with secularisation and post-secularism, which results in the emergence of the so-called "new spirituality". The point of reference for these reflections is the conviction that spirituality itself is insufficient in the life of a person, but that it must be complemented in some form by religion as a system of relations between the divine sphere and the individual, expressed in spiritual experience, doctrinal and moral truths, worship activities and the existence of a specific religious community. Thus, the outlined issues determine the plan for these analyses.

\section{Secularisation, secularism, post-secularism}

For our considerations, one should first outline the spiritual background of the epoch in which the modern man lives. It seems that it is characterised, on the one hand, by the planned elimination and dying out of religion, and on the other hand, by its appreciation and rebirth.

Janusz Mariański, the Polish sociologist of religion, emphasises that we are witnessing a process of secularisation taking place before our eyes. ${ }^{1}$ The term "secularisation" itself is not new. It appeared in the 17th century, in the context of the German religious wars and the French Revolution. Initially, it defined

\footnotetext{
${ }^{1}$ Janusz MARIAŃSKI, Religijność społeczeństwa polskiego w perspektywie europejskiej. Próba syntezy socjologicznej, Kraków, Nomos, 2004, 45-46.
} 
the process of liquidation of some church property and liberation of a certain sector from the power of the Church. It was then applied to culture as contrary to religion. ${ }^{2}$ Secularisation was very intense in the 1950s and 1960s. It had a theoretical background in the views of August Comte, Karl Marx, Max Weber and Emil Durkheim, who pointed the loss of influence of religion on society, its reduction to the private sphere, a decrease in religious activity, the diminishing of religious needs and religion itself. The processes of modernisation, urbanisation and industrialisation were conducive to this. ${ }^{3}$ Secularisation was affected by civilisation. It was associated primarily with the European and Christian culture. ${ }^{4}$ Secularisation in the above sense is not present in other cultures and religions. Moreover, secularisation is still an integral part of the European culture. What, then, are its fundamental manifestations?

Peter Berger, an American sociologist, describes secularisation as a process by which different sectors of society and culture become independent of the domination of religious institutions and symbols. ${ }^{5}$ Meanwhile, for the Canadian philosopher Charles Taylor, secularisation has three main dimensions. First, faith in God was shifted from the public to the private sphere. Secondly, secularisation manifests itself in the diminishing of faith and religious practices. Thirdly, it involves treating faith as one of many life options. ${ }^{6}$ Secularisation is seen to take different forms. Their common feature, however, is that religion loses its real influence on personal and social dimension of human life.

However, a distinction should be made between secularisation and secularism. Secularisation is a social process that results in religious values and institutions losing their influence on individual and social life. Secularism, on the other hand, is a form of ideology whose supporters deny the presence of religion in social life and perceive it only in the temporal perspective. ${ }^{7}$ Secularism can also be seen as a form of humanism whose proponents strive to exclude

${ }^{2}$ Mieczysław CISŁO, Sekularyzm wyzwaniem dla Kościoła, in: Gabriel Witaszek (ed.), Tertio millennio adveniente. U progu trzeciego tysiaclecia, Lublin, Katolicki Uniwersytet Lubelski, 2000, 246.

${ }^{3}$ Janusz MARIAŃSKI, Religia $i$ Kościót $w$ społeczeństwie pluralistycznym. Polska lat dziewięćdziesiatych, Lublin, Katolicki Uniwersytet Lubelski, 1993, 8-9; idem, Sekularyzacja $i$ desekularyzacja w nowoczesnym świecie, Lublin, Katolicki Uniwersytet Lubelski, 2006, 2324; idem, Religia w społeczeństwie ponowoczesnym. Studium socjologiczne, Warszawa, Oficyna Naukowa, 2010, 75-78.

${ }^{4}$ Jose CASANOVA, The Secular, Secularizations, Secularisms, in: Craig Calhoun, Mark Juergensmeyer, Jonathan van Antwerpen (eds.), Rethinking Secularism, New York, Oxford University Press, 2011, 56, 61-66, 72-73; Charles TAYLOR, A Secular Age, Cambridge (Ma)-London, Harvard University Press, 2007, 21, 425, 433.

${ }^{5}$ Peter BERGER, Swięty baldachim. Elementy socjologicznej teorii religii, trans. Włodzimierz Kurdziel, Kraków, Nomos, 1997, 150.

${ }^{6}$ Charles TAYLOR, Sources of the Self. The Making of the Modern Identity, Cambridge (Ma), Harvard University Press, 2001, 401-402; idem, A Secular Age, 1-4.

7 Maciej HUŁAS, Źródła sekularności. Analiza wybranych aspektów sekularyzacji, Studia Nauk Teologicznych PAN, 9 (2014) 43-46; Paweł MAZANKA, Refleksje o filozoficznych źródtach sekularyzacji i sekularyzmu, Studia Nauk Teologicznych PAN, 9 (2014) 57-64. 
from the consciousness of the individual all religiousness and all transcendent reality as harmful to man. ${ }^{8}$ It seems that secularism in social life is primarily a form of ideology, i.e. a community of interests of members of a particular group, striving to implement them. In this case, it is in the interest of this group to adopt a strategy aimed at cleansing the public sphere of all manifestations of religion.

It should be noted, however, that since the mid-1970s there has been a reversal of the belief that secularisation is progressing. However, new forms of experiencing sacrum and the need for religion in the public sphere were noted. There was also an attempt to redefine the position of religion and to strive for its rehabilitation. However, the revival of religion was not identified with the revitalisation of ecclesiastical religiousness. Since the 1990s, there has been a noticeable transition from an external, institutional and ritual religion to internal, individual and subjective religiousness. ${ }^{9}$ Therefore, religion did not disappear but changed its form. It has retained its importance in determining the identity and meaning of human life. ${ }^{10}$

The thesis of progressive secularisation has been criticised for several reasons. In particular, the close correlation between secularisation and modernisation has been questioned. It has been observed that secularisation is a Western European phenomenon only. If it occurs, it has an institutional dimension. In the life of individuals, we observe the development of new forms of traditional religions and spirituality. Individual states are also seen as not neutral towards religion. The removal of religion impoverishes the socio-political sphere, in which religious beliefs are the foundations of many ideas, e.g. human rights. ${ }^{11}$

Berger emphasises that the conviction of living in a secularised world is false. He believes that the world is more religious today. Moreover, secularisation at the social level is not connected with secularisation at the level of human consciousness. Many religious beliefs and practices are sustained by individuals in new forms and with greater zeal. ${ }^{12}$

Therefore, it is not secularisation that is talked about, but rather the revival of religious life. ${ }^{13}$ We have to do with de-secularisation (Peter Berger), re-spiritualisation (Peter Zulehner), de-privatisation (Jose Casanova), return of religion (Christoph Bochinger), quasi-religion (Marty Martin), religion implicite

\footnotetext{
${ }^{8}$ Janusz MARIAŃSKI, Sekularyzacja, desekularyzacja, nowa duchowość. Studium socjologiczne, Kraków, Nomos, 2013, 195-205.

9 Mariański, Religia i Kościół w społeczeństwie pluralistycznym..., 10-11, 18; idem, Sekularyzacja i desekularyzacja w nowoczesnym świecie, 39-48.

${ }^{10}$ Mariański, Sekularyzacja, desekularyzacja, nowa duchowość..., 85.

${ }^{11}$ Tadeusz BUKSIŃSKI, Publiczne sfery i religie, Poznań, Uniwersytet im. Adama Mickiewicza, 2011, 206-211.

${ }^{12}$ Peter L. BERGER, The Desekularization of the World. A Global Overview, in: Peter L. Berger (ed.), The Desekularization of the World. Resurgent Religion and World Politics, Washington, Ethics and Public Policy Center, 1999, 2-3.

${ }^{13}$ Mariański, Sekularyzacja, desekularyzacja, nowa duchowość..., 116-117.
} 
(Günter Thomas), non-doctrinal religion (Milton Yinger), spiritual revival (Paul Zulehner), spiritual revolution (David Tacey), new religious scenery (Christoph Bochinger), return of gods (Friedrich Graf), new openness to religion (Ulf Jonsson), post-confessional society (Edgar Wunder) or post-secular society (Jürgen Habermas).$^{14}$ It seems that at the end of the $20^{\text {th }}$ century a "post-secular turn" occurred, whose consequences are now being seen. Post-secularism, therefore, means the return of a religion as a "strong actor" in social life.

Jan Andrzej Kłoczowski, a Polish philosopher of religion, notes that postsecularism emerged at the turn of the 19th and 20th centuries. The emergence of this phenomenon was associated with Weber's diagnosis of the disenchantment of the world and with the need for a sense of life existing in people. ${ }^{15}$ One can say that post-secularism rediscovered religion as a source of meaning for human existence.

In modern times, religion seems to be returning in several forms, e.g. fundamentalist attitudes, philosophical reflection, spirituality. ${ }^{16}$ Post-secularism does not mean, therefore, the return of the former religious order, but rather the opening of other perspectives and the search for a new spiritual experience. ${ }^{17}$ Therefore, one must say that religion is undergoing a metamorphosis. Moreover, Pope Benedict XVI was right when he noted that man is not seeking faith as relation with personal God, but an individual spiritual experience.

Religion, therefore, returns mainly in the form of spirituality, in which the subjective way of life and self-fulfilment are emphasised. Moreover, contemporary spirituality does not adopt institutionalised forms. ${ }^{18}$ Therefore, when talking about a possible crisis in religion, one should emphasise the collapse of institutionalised religion. One increasingly often meets with different kinds of extra-ecclesial religiousness and spirituality. ${ }^{19}$

Therefore, the process of deinstitutionalisation is an important sign of the post-secular era; it is in the distance towards religious communities and in constructing one's own spiritual life form. This process is also sometimes re-

\footnotetext{
${ }^{14}$ Janusz MARIAŃSKI, Globalizacja $i$ kościoty - sprzymierzeńcy czy konkurenci?, in: Maria Libiszowska-Żółtkowska (ed.), Religia i religijność w warunkach globalizacji, Kraków, Nomos, 2007, 111.

${ }^{15}$ Jan Andrzej KŁOCZOWSKI, $U$ źródeł nowoczesnego myślenia o religii. Szkice $z$ filozofii religii dla humanistów, Vol. II, Kraków, Instytut Myśli Józefa Tischnera, 2018, 33-40, 55.

${ }^{16}$ Anselm GRÜN, Tomaš HALÍK, Bóg zagubiony. Wiara w objęciach niewiary, trans. Marek Chojnacki, Kraków, Wydawnictwo Apostolstwa Modlitwy, 2017, 147-155.

${ }^{17}$ Michał JANUSZKIEWICZ, O postsekularyzmie z perspektywy hermeneutycznej, in: Mieszko Ciesielski, Katarzyna Szewczyk-haake (eds.), Szkoda, że Cie tu nie ma. Filozofia religii a postsekularyzm jako wyzwanie nowych czasów, Kraków, Instytut Myśli Józefa Tischnera, 2018, 2024.

${ }^{18}$ Andrzej DRAGUŁA, Powrót wiary, religii czy duchowości? Teolog wobec postsekularyzmu, in: Mieszko Ciesielski, Katarzyna Szewczyk-Haake (eds.), Szkoda, że Cię tu nie ma. Filozofia religii a postsekularyzm jako wyzwanie nowych czasów, Kraków, Instytut Myśli Józefa Tischnera, 2018, 40-41.

${ }^{19}$ Mariański, Sekularyzacja, desekularyzacja, nowa duchowość..., 93.
} 
ferred to as "de-ecclesiastication". In pre-modern societies, the Church defined and transmitted certain truths, values, norms and ceremonies with which individuals identified themselves. This identification may be completely absent in the modern societies. ${ }^{20}$

The process of deinstitutionalisation also results in the emergence of the phenomenon of "faith without affiliation". An individual does not want to be a formal member of a particular religious community and to accept its way of life. He rather prefers to decide on his own faith based on satisfying individual emotional needs. ${ }^{21}$ Reduction of the faith to subjective emotions has resulted that the objective truth lost its importance.

The decline of religious institutions and the emergence of "faith without affiliation" are associated with the process of individualisation..$^{22}$ Many people want to be more responsible for their own fate and strive for self-determination. Therefore, they try to free themselves from traditional structures and social bonds. $^{23}$

This process results in a growing interest in extra-ecclesial forms of sacrum. In this way, a specific market of religion is created, where individuals behave as consumers. ${ }^{24}$ Their religiousness is also syncretic. Extra-ecclesial religiousness is therefore associated with the transition from heteronomy to autonomy, from institutions to deinstitutionalisation, from traditions to de-traditionalisation. ${ }^{25}$

Because of the individualisation process, the individuals gain awareness of their "I" and become the ultimate authority legitimising life choices and preferences. They arrange their relations by calculating the benefits and losses. They also want to be more authentic concerning their own desires. ${ }^{26}$ The individuals are interested in the self-fulfilment of their own personality. The spiritual traditions they treat as a limitation of the personality. ${ }^{27}$ The lack of them is supposed to provide them with greater development opportunities. ${ }^{28}$ For this reason, proponents of the traditional understanding of religion accuse the supporters of its post-secular version a kind of anarchy. ${ }^{29}$

\footnotetext{
${ }^{20}$ Mariański, Religia w społeczeństwie ponowoczesnym..., 101-103, 174.

${ }^{21}$ Mariański, Sekularyzacja, desekularyzacja, nowa duchowość..., 94-96.

${ }^{22}$ Janusz MARIAŃSKI, Kościót katolicki w społeczeństwie obywatelskim. Refleksje socjologiczne, Lublin, Katolicki Uniwersytet Lubelski, 1998, 50, 52.

${ }^{23}$ Mariański, Sekularyzacja, desekularyzacja, nowa duchowość..., 109-112.

${ }^{24}$ Beata GUZOWSKA, Duchowość ponowoczesna. Idee, perspektywy, prognozy, Rzeszów, Uniwersytet Rzeszowski, 2011, 52-53, 56.

${ }^{25}$ Mariański, Sekularyzacja i desekularyzacja w nowoczesnym świecie, 87-89.

${ }^{26}$ Thomas LUCKMANN, Niewidzialna religia. Problem religii w nowoczesnym społeczeństwie, trans. Lucjan Bluszcz, Kraków, Nomos, 2011, 183-185; Mariański, Religia w społeczeństwie ponowoczesnym..., 50-53.

${ }^{27}$ Agata BIELIK-ROBSON, Inna nowoczesność. Pytania o współczesna formułe duchowości, Kraków, Universitas, 2000, 265-269, 272.

${ }^{28}$ Mariański, Religia i Kościót w społeczeństwie pluralistycznym..., 27-28, 42.

${ }^{29}$ Jens KOEHRSEN, How Religious Is the Public Sphere? A Critical Stance on the Debate About Public Religion and Post-Secularity, Acta Sociologica, 3 (2012) 274-283.
} 
In this way, religion is individualised. The individual can choose from a variety of religious orientations, models, values and norms. He becomes a kind of creator of his religiousness. An individual moves from having a religion as a cultural heritage to being religious without any intermediary. ${ }^{30}$ The religiousness of an individual is therefore subject to evolution from great to small transcendence, that is to say, from God to the transcendence of his own nature. ${ }^{31}$ Nevertheless, an individual is still open to some mystery of the reality. ${ }^{32}$

Therefore, one must say that the post-secular turn has resulted in a real revival and appreciation of religious life, but also - with its profound metamorphosis. It is highly individualised and detached from the institutional dimension. However, an individual has not lost his spiritual needs. However, he wants to satisfy them in more independent, personal experience and emotional way. The current religious situation seems to be characterised by pluralism of forms and the emergence of a new form of spirituality. Let us, therefore, look at the latter, which aspires to be the answer to an individual's needs and searches.

\section{The nature of contemporary spirituality}

Many researchers and theoreticians of social and religious life now talk about the appearance of so-called "new spirituality". The term is used to describe a form of non-institutional religiousness that has the following features: fragmentation, chaos, causality, spontaneity, emotionality and reflectiveness. ${ }^{33}$

However, it should be noted that the expression "new spirituality" ("postmodern spirituality") has not yet been clearly defined. It bases on the ideas of Tales, Plotinus, Eriugena, Friedrich Schelling, Novalis, Jakob Boehme, Friedrich Schleiermacher, Albert Schweitzer, Anthony de Mello, Alfred Whitehead, Pierre de Chardin and Martin Heidegger. Two important elements are present in the concept of "new spirituality": metaphysical and psychological. The metaphysical element is based on esotericism, theosophy and gnosis. The psychological element is visible in the emphasis on mystical experience and in the criticism of the thesis of the central position of man in the cosmos. The "new spirituality" must be understood as experience based on the sacred sphere and as a form of spiritual life. ${ }^{34}$

\footnotetext{
${ }^{30}$ Mariański, Sekularyzacja i desekularyzacja w nowoczesnym świecie..., 113-116; idem, Religia w społeczeństwie ponowoczesnym..., 21, 180-184, 186; idem, Sekularyzacja, desekularyzacja, nowa duchowość..., 104.

${ }^{31}$ Mariański, Sekularyzacja i desekularyzacja w nowoczesnym świecie..., 103-105, 151; idem, Religia w społeczeństwie ponowoczesnym..., 21, 151, 216.

${ }^{32}$ Grün, Halík, Bóg zagubiony..., 122-123.

${ }^{33}$ Mariański, Religia w społeczeństwie ponowoczesnym..., 95, 161, 163, 185, 199; idem, Sekularyzacja, desekularyzacja, nowa duchowość..., 148-149.

${ }^{34}$ Guzowska, Duchowość ponowoczesna..., 9, 19-21, 101, 151, 156-157.
} 
The "new spirituality" also refers to the spiritual search itself, which is sometimes connected with the need to respond to fundamental moral and existential dilemmas. Man becomes a "spiritual wanderer". ${ }^{35}$ Above all, he seeks the meaning of life. ${ }^{36}$ Religion is understood as everything connected with the sense of human existence. The issue of the meaning of life is increasingly important. The sense is associated only with the spiritual experiences of a human being. ${ }^{37}$ For this reason, this "spiritual wanderer" sometimes resembles a being described by Gilles Deleuze as "schizo", i.e. someone wandering around aimlessly in his life. It is man searching for meaning, but unable to find it.

The "new spirituality" lies outside the formal structures. There is also no reference to personal transcendental reality. Transcendent God is sometimes reduced to some form of impersonal and immanent sacrum, primary depth of reality and meaning of life. An important role in the "new spirituality" is played by the human "I" with its inner experiences, personal searching and the need for self-fulfilment. The emphasis is put on emotions, healing and integration of personality. ${ }^{38}$

One of the elements of the "new spirituality" is the so-called default religiousness. Sometimes it takes on agnostic, sceptical and atheistic forms. ${ }^{39}$ Some also talk of atheistic spirituality. The spirit is treated as a function of the brain or as an act of exercise. The Absolute is then not a personal God, but a being that encompasses the whole reality. The spiritual life consists then in establishing relations with the mystery of being. Atheistic spirituality is, therefore, immanent because it is limited to contact with the universe and experiencing unity, freedom and peace. ${ }^{40}$

In the "new spirituality", there are also two visions of the future: the new man and the new world. In these two visions, the emphasis is on the transformation of consciousness and the structures of social life. Especially important is the transformation of consciousness, which is related to the intensity of the spiritual life, the relativity of sensory data, the activation of the subconscious, the experience of new energy and harmony with the cosmos. ${ }^{41}$

\footnotetext{
${ }^{35}$ Mariański, Sekularyzacja, desekularyzacja, nowa duchowość..., 148, 181.

${ }^{36}$ Anthony GIDDENS, Nowoczesność $i$ tożsamość. "Ja" $i$ społeczeństwo $w$ epoce późnej nowoczesności, trans. Alina Szulżycka, Warszawa, Polskie Wydawnictwo Naukowe, 2012, 276277.

${ }^{37}$ Mariański, Religia w społeczeństwie ponowoczesnym..., 46-47, 161.

${ }^{38}$ Mariański, Religia w społeczeństwie ponowoczesnym..., 201-220; idem, Sekularyzacja, desekularyzacja, nowa duchowość..., 154-162.

${ }^{39}$ Andrzej WÓJTOWICZ, Wspótczesna socjologia religii. Założenia, idee, programy, Tyczyn, Wyższa Szkoła Społeczno-Gospodarcza, 2004, 48.

${ }^{40}$ Andre COMTE-SPONVILLE, Duchowość ateistyczna. Wprowadzenie do duchowości bez Boga, trans. Elżbieta Aduszkiewicz, Warszawa, Czarna Owca, 2011, 143-145, 149-153, 158, 163, 170194, 203-207.

${ }^{41}$ Guzowska, Duchowość ponowoczesna..., 19-20, 152, 154-155, 158-160.
} 
It should be stressed that the character of the "new spirituality" is related to the contemporary social and cultural reality, in which the existing lifestyle, values, and norms are no longer binding in the face of new challenges shaped by globalisation processes. Its main features are changeability, differentiation, self-creation, self-fulfilment, revaluation of values, free market, consumerism, liberalism, pluralism of communities..$^{42}$ They are also expressed in a "new spirituality", in which individual's search is absolutised. It seems to have no specific purpose but to respond to his temporary needs. It is not directed towards a transcendent being, because the focus on the immanence of the world seems to be sufficient.

Therefore, a question arises about the sufficiency of spirituality, understood in this way. Can man reduce his spiritual life to a constant search, experience, emotions, or does he need some permanent points of reference? Is it sufficient for him to have a "small transcendence", or does he need a "large transcendence"? Is subjective spirituality sufficient, or is a more objective religion necessary in human life?

\section{3. "New spirituality" and religion}

Moving on to the discussion of the relationship between religion and spirituality, one should first ask about the nature of religion itself, because it is a complex phenomenon. There are about 10,000 religions, which are systems of beliefs and practices that differ from one another. However, we can find common elements in them.

Religion is understood primarily as a transcendent event in which a person transgresses him/herself and approaches a mystery. Religion, therefore, satisfies the need for transcendence and its essence is the experience of the supernatural. ${ }^{43}$

In fact, considering its etymology, the word "religion" itself indicates a kind of relationship between man and differently understood Absolute. This relationship manifests itself in an individual experience, a beliefs system, a cult or a community of believers. ${ }^{44}$ It is worth emphasizing that true religion arises from supernatural revelation. Its essential elements include spiritual experience, doctrine, ritual and community.

Let us, therefore, look at the relationship between religion and spirituality. Christian religion and spirituality will be the point of reference in this case. It

\footnotetext{
${ }^{42}$ Ibidem, 145-150.

${ }^{43}$ Mariański, Religia i Kościót w społeczeństwie pluralistycznym..., 5-6.

${ }^{44}$ Zofia J. ZDYBICKA, Człowiek $i$ religia. Zarys filozofii religii, Lublin, Katolicki Uniwersytet Lubelski, 1993, 280-281, 359-368.
} 
is noteworthy that proper spirituality is an inseparable element of Christianity. Therefore, it is worth asking the question: how should it be understood?

Classically understood spirituality was usually combined with exercises. They constituted a practical action program. Their goal was the process of internal transformation, which was expressed in shaping appropriate external relationships (metanoia). ${ }^{45}$ So spirituality was related to spiritual experiences, expressions and practices. ${ }^{46}$ According to Tomáš Špidlik, the historian of Eastern Christian spirituality, spirituality is a multifaceted concept. According to him, spirituality, especially Christian spirituality, is, above all, a life within and with the Holy Spirit, who gives strength, harmony and meaning. ${ }^{47}$ The French philosopher and theologian Reginald Garrigou-Lagrange, believes that spirituality is a higher form of internal conversation that man conducts with himself, which turns into a conversation with God. From now on, man strives to seek God in everything. In consequence, God permeates the whole of man and his life. ${ }^{48}$ According to the Polish theologian Marek Chmielewski, spirituality is a historically conditioned way of understanding and living a religious truth, just as it was accepted, experienced and transmitted in an authoritative way within a religious community. ${ }^{49}$ Therefore, we can see that Christian spirituality understood in a classic way can be seen as equivalent to a certain lifestyle. It consists in leading man through the Holy Spirit, seeking and living a divine truth. Two issues should be stressed. First, truth in Christianity has a personal dimension (Jesus of Nazareth) and an existential dimension (experience). The life according to this truth is equivalent to the spiritual life. Secondly, Christian spirituality has not only an individual dimension but also a communal one. It corresponds to the social nature of man. Moreover, certain rites and ceremonies are its important element and their aim is to enable a relationship with God and to integrate a community of believers.

The importance of the social element in man's religious life is also emphasised by the Canadian philosopher Charles Taylor. Religion is for him a sacramental community, in which people participate together through liturgy. Liturgy unites the believer with supernatural beings and with fellow believers. ${ }^{50}$

\footnotetext{
${ }^{45}$ John COTTINGHam, Spiritual Dimension. Religion, Philosophy and Human Value, New York, Cambridge University Press, 2006, 5.

${ }^{46}$ Mariański, Religia w społeczeństwie ponowoczesnym..., 200-201; idem, Sekularyzacja, desekularyzacja, nowa duchowość..., 152.

${ }^{47}$ Tomáš ŠPIDLÍK, $U$ źródeł światłości. Podręcznik życia chrześcijańskiego, trans. Juliusz Zychowicz, Warszawa, Wydawnictwo Księży Marianów, 1991, 1-12.

${ }^{48}$ Reginald GARRIGOU-LAGRANGE, Trzy okresy życia wewnętrznego wstępem do życia $w$ niebie, trans. Teresa Landy, Niepokalanów, Wydawnictwo Ojców Franciszkanów, 1998, 15-16, 4652 .

${ }^{49}$ Marek CHMIELEWSKI, Duchowość, in: Marek Chmielewski (ed.), Leksykon duchowości katolickiej, Lublin-Kraków, Wydawnictwo "M”, 2002, 230.

${ }^{50}$ Charles TAYLOR, Świecka epoka i różne ścieżki wiary, trans. Andrzej Pawelec, Znak, 10 (2010) 28-29.
} 
The importance of the ceremonial in the spiritual life of man has also been pointed out by the researcher of Hebrew literature, Evan Moffic. He claims that the ceremonial gives order to the world and a metaphysical character to the actions. It initiates spiritual experiences and sets them within a certain framework. The ceremonial has vertical and horizontal dimension. ${ }^{51}$ Indispensable components of the liturgical ceremonial are symbols, which, according to religious thinker Paul Tillich, reveal the supernatural reality and allow to participate in it. ${ }^{52}$ Some religious scholars, such as Mircea Eliade and Gerardus van der Leeuw, also speak in a similar tone.

Therefore, Taylor cannot accept the contemporary understanding of spirituality as the fundamental form of spiritual life. In his opinion, spirituality cannot be reduced to individual search, without any reference points. ${ }^{53}$ According to Taylor, the emergence of such a form of spirituality is a consequence of a lack of trust in the hitherto existing lifestyles defined by different Churches, which do not stimulate to conduct a personal search. ${ }^{54}$ Therefore, Taylor sees the contemporary approach to spirituality as inadequate.

Spiritual development should, therefore, take into account and appreciate religion with its communal and ritual dimension. Otherwise, it will face several dangers. First, individualised spirituality will easily transform into an undefined sphere of subjectivism and arbitrariness. ${ }^{55}$ Secondly, without communication with other people, man can become a spiritual narcissus. ${ }^{56}$ Thirdly, spirituality without concrete religious forms seems to be extremely ephemeral. ${ }^{57}$ Fourthly, without the structures provided by the religious community, man will not be able to develop his spiritual experience. ${ }^{58}$ Fifthly, a religious community also satisfies important human needs, e.g. sense of belonging and identity. ${ }^{59}$ Sixthly, spirituality cannot only be reduced to experiences and sensations, because it has a cognitive content, which must be objective, inter-subjectively meaningful and communicable. The individualised form of spirituality seems to be insufficient in human life, but it should be complemented by religion, with its social,

\footnotetext{
${ }^{51}$ Evan MOFFIC, Co każdy chrześcijanin powinien wiedzieć o święcie Paschy? Co oznacza i dlaczego ma znaczenie?, trans. Marcin Holdenmajer, Warszawa, Dobry Skarbiec, 2018, 127-128.

${ }^{52}$ Paul TILLICH, Dynamika wiary, trans. Adam Szostkiewicz, Poznań, W drodze, 1987, 62-71.

${ }_{53}^{5}$ Taylor, A Secular Age, 506-510, 512-513.

${ }^{54}$ Charles TAYLOR, The Church speaks - to Whom?, in: Charles TAYLOR, Jose CASANOVA, George F. McLEAN (eds.), Church and People: Disjunctions in a Secular Age, Washington, Council for Research in Values and Philosophy, 2012, 18-20.

${ }^{55}$ Mariański, Religia w społeczeństwie ponowoczesnym..., 192.

${ }^{56}$ Agnieszka KACZMAREK, Charles Taylor wobec odwagi duchowości, in: Anna GRZEGORCZYK, Jacek SÓJKA, Rafał KOSCHANY (eds.), Fenomen duchowości, Poznań, Uniwersytet im. Adama Mickiewicza, 2006, 229.

${ }^{57}$ Mariański, Sekularyzacja, desekularyzacja, nowa duchowość..., 171.

${ }^{58}$ Mariański, Religia w społeczeństwie ponowoczesnym..., 213.

${ }^{59}$ Claire M. RENZETTI, Daniel J. CURRAN, Kobiety, mężczyźni i społeczeństwo, trans. Agnieszka Gromkowska-Melosik, Warszawa, Polskie Wydawnictwo Naukowe, 2005, 461.
} 
doctrinal and cult-related dimensions, owing to which the authenticity of spiritual experiences can be objectified and verified.

Taylor also stresses that community bonds cultivated through religious practices continue to play an important role. He gives five arguments. First, through community bonds, man acquires and maintains his religious identity. Secondly, some types of religious experience are more intense when they are shared with others. ${ }^{60}$ Thirdly, religious practices can still help to revive human relationship with God. However, some of them lost their importance. It is, therefore, necessary not to be afraid to introduce new practices that would better respond to the contemporary mentality of man. ${ }^{61}$ Fourthly, religious practices enable access to traditional forms of faith, especially in specific situations of human existence (e.g. death), which are still determined by religious rites. Fifthly, they enable the transformation of spiritual inspirations into regular activity. ${ }^{62}$ The community and its religious practices must not, therefore, be underestimated in the spiritual development of man, but rather their importance must be appreciated.

\section{Conclusions}

The above analyses were an attempt to determine the character of the contemporary form of spirituality and to show its links with religion. They emphasised that the new variety of spirituality appeared because of processes taking place in social life. The point of reference for these reflections was the conviction that spirituality alone is insufficient in the life of a person, but it must be complemented by some form of religion as a bond between man and God and as a collection of beliefs and practices of a community of believers.

It should be noted, above all, that the understanding of spirituality itself has changed. In the past, it was seen as a deepened religiousness and a specific lifestyle according to divine truth. The whole human life, therefore, was ultimately directed towards God himself as the principal of his unity, harmony and meaning. Spirituality was vertical, transcendental and communal. In the modern times, it was separated from the Absolute and community. The autonomous human subject became the creator of new spirituality as a way to satisfy his personal needs, spiritual searches and emotional contact with the mystery of nature. Spirituality thus took on a new character - horizontal, immanent and individual.

\footnotetext{
${ }^{60}$ Charles TAYLOR, Varieties of Religion Today. William James Revisited, Cambridge (Ma)-London, Harvard University Press, 2003, 22-29, 111-116.

${ }^{61}$ Charles TAYLOR, Concluding Reflections and Comments, in: James L. HEFT (ed.), A Catholic Modernity? Charles Taylor's Marianist Award Lecture, New York-Oxford, Oxford University Press, 1999, 108.

${ }^{62}$ Taylor, A Secular Age..., 516-522.
} 
It seems, however, that the domination of subjectivism, arbitrariness and temporality of experiences may lead to spiritual aberrations. A specific framework is needed to enable man to maintain and develop his spiritual experiences and to continue, deepen and intensify them. Thanks to this framework, it will also be possible to objectify and verify individual experiences, and thus protect oneself from spiritual illusions. It seems that a religion whose revival is postulated in the era of post-secularism, with its system of beliefs, institutions and rites, which are at the service of the spiritual transformation of human being, is in this respect a great help and support for a person who wants to realise the need for a "deeper life".

The dynamism of the spiritual existence of man, therefore, demands to be supplemented by religious structures. Of course, they only make sense as far as they are able to sustain, develop and direct the internal experience. However, if they suppress or deform them through unnecessary formalisation or juridification, then they do not fulfil their role and will require the necessary modification.

\section{Karol Jasiński* \\ Postsekularizam i suvremena duhovnost \\ Sažetak}

Autor članka je pokušao definirati karakter suvremenog, novog oblika duhovnosti i pokazati njezinu povezanost s religijom. Pojava nove duhovnosti rezultat je procesa koji se odvijaju u društvenom životu. $S$ jedne strane je duhovnost obilježena sekularizacijom i sekularizmom, a s druge strane desekularizacijom i postsekularizmom. U radu se polazi od pretpostavke da nova duhovnost sama po sebi nije dovoljna u čovjekovu životu, već on ima stalnu potrebu njezina nadograđivanja na različitim dimenzijama religije. Članak se sastoji od tri dijela. U prvom dijelu se raspravlja o sljedećim pojavama: sekularizacija, sekularizam, postsekularizam. Drugi dio analizira fenomen nove duhovnosti. U trećem dijelu se pitanje religije pokušava kontekstualizirati kroz tradicionalno razumijevanje duhovnosti, a potom i odrediti kao dio prirodnog, ponekad i paradoksalnog, odnosa religije i duhovnosti.

Ključne riječi: duhovnost, duhovna potraga, individualizam, institucija, postsekularizam, religija.

(na hrv. prev. Vlaho Kovačević)

\footnotetext{
* Izv. prof. dr. sc. Karol Jasiński, Varmijsko i mazurijsko sveučilište, Teološki fakultet, Olsztyn; Hozjusza 15, 11-041 Olsztyn, Poljska; e-mail: karol.jasinski@uwm.edu.pl.
} 